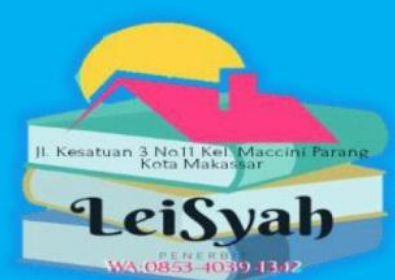

ISBN : 978-623-7045-04-5
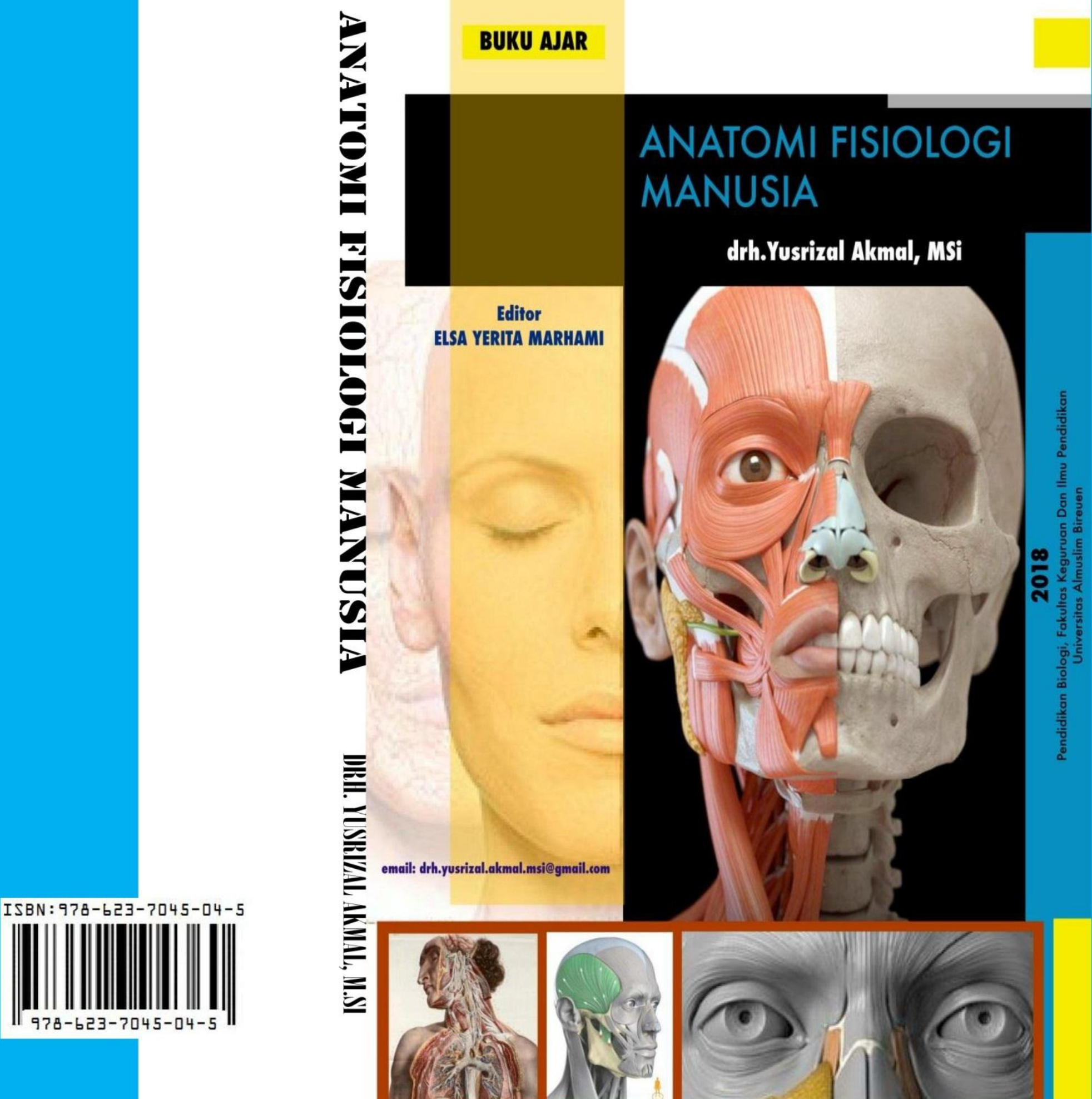


\section{ANATOMI FISIOLOGI MANUSIA}

\section{drh.Yusrizal Akmal, MSi}

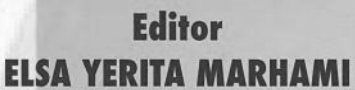

email: drh.yusrizal.akmal.msi@gmail.com

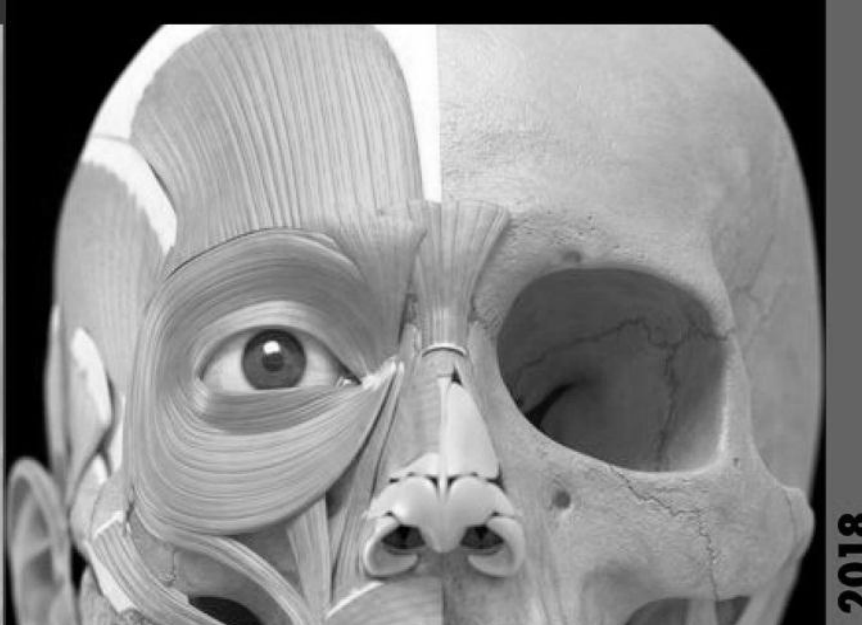

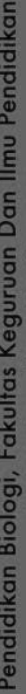
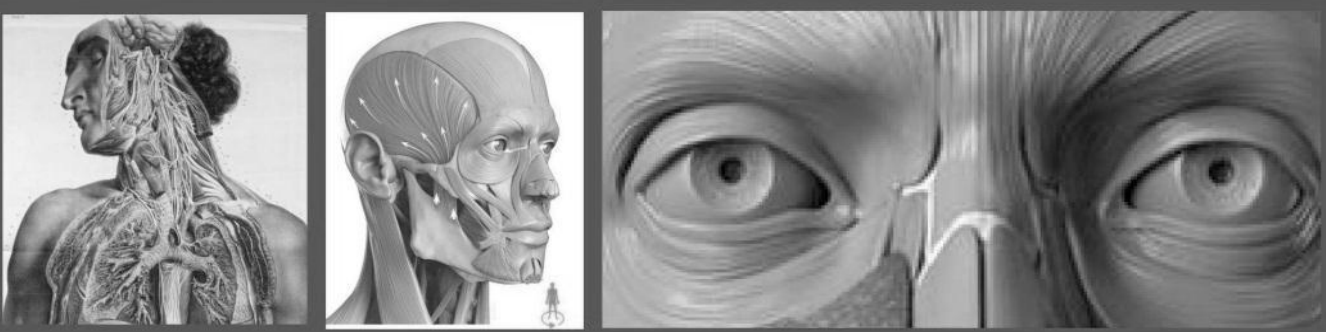
Sanksi Pelanggaran Pasal 72

Undang-Undang Nomor 19 Tahun 2002 Tentang Hak Cipta

1. Barang siapa dengan sengaja dan tampa hak melakukan perbuatan Sebagaimana dimaksud dalam pasal 2 ayat (1) atau pasal 49 ayat (1) dan ayat 2 dipidana dengan pidana penjara masing-masing paling singkat 1 (satu) bulan dan/atau denda paling sedikit Rp. 1.000.000,- (satu juta rupiah), atau pidana penjara paling lama 7 (tujuh) tahun dan/atau denda paling banyak Rp. 5.000.000.000,(lima milyar rupiah).

2. Barang siapa dengan sengaja menyiarkan, memamerkan, mengedarkan atau menjual kepada umum suatu ciptaan atau barang hasil pelanggaran Hak Cipta terkait bagaimana dimaksud pada ayat (1) pidana dengan pidana penjara paling lama 5 (lima) tahun dan/atau denda paling banyak Rp. 500.000.000,- (lima ratus iuta rudiah).

\section{(c) Hak Cipta pada pengarang}

Dilarang mengutip sebagian atau memperbanyak sebagian atau seluruh isi buku ini dengan cara apapun tampa seizin penerbit, kecuali untuk kepentingan penulisan artikel atau karangan ilmiah.

Judul Buku : : ANATOMI FISIOLOGI MANUSIA

Penulis : drh.Yusrizal Akmal, M.Si

Halaman : $\mathrm{v}+210$

ISBN : : 978-623-7045-04-5

Ukuran Buku : $23 \times 15 \mathrm{~cm}$

Layout Oleh : Sulaiman Sahabuddin Al Karawish

Penerbit Leisyah

Jalan Kesatuan 3 No. 11 Kelurahan Maccini Parang

Hp. 085263024953 Wa. 085340391342

Email. Sulaimansalman105@yahoo.com 


\section{KATA PENGANTAR}

Segala puji bagi Allah yang telah mengajarkan manusia dengan perantara al-qalam, tentang apa yang tidak diketahuinya. Shalawat serta salam semoga senantiasa tercurahkan kepada Sang Maha Guru sejati Nabiullah Muhammad Shallallahu 'Alaihi Wasallam, atas jasa besar beliaulah sehingga alam jagat ini bisa tercerahkan. Semoga shalwat serta salam juga tercurahkan kepada keluarganya, para sahabatnya, dan seluruh manusia yang masih konsekuen mengikuti petunjuk dan ajarannya.

Buku ini yang ada ditangan pembaca ini, adalah buku yang ditulis dengan maksud untuk membantu menjelaskan tentang Anatomi Fisiologi Manusia dalam ilmu kesehatan.

Sajian dalam buku ini merupakan hasil kajian literatur yang dilakukan secara mendalam dalam rangka menambah khasanah dan referensi dalam bidang kesehatan.

Akhirnya penulis berharap, semoga buku kecil ini bisa memberikan manfaat. Hanya kepada Allah kita memohon ampun atas segala kehilafan dan kekeliruan yang mungkin terdapat dalam tulisan ini.

Penulis 


\section{DAFTAR ISI}

KATA PENGANTAR_iii

DAFTAR ISI_iv

\section{BAB I}

KOMPOSISI DAN KOMPONEN 'TUBUH MANUSIA_I

\section{BAB II}

SISTIEM MUSKULUSKELEITAL_23

BAB III

SISTIEM PENCERNAAN_48

BAB IV

SISTIEM PERNAPASAN_73

BAB V

SISTIEM KARIDIOVASKULER_92

BAB VI

SIRKULASI DARAH_116

BAB VII

SISTIEM PERSARAFAN_133

BAB VIII

SISTEY URINARIA_152 


\section{BAB IX}

SIS'IEM REPRODUKSI_170

\section{BAB X}

SISTEM ENDOKRIN_187

\section{BAB XI}

SISTIEM PENGINDERAAN_199

DAFTAR PUS'TAKA_205 